\section{Copyright vs patents for software}

\section{Washington}

DisAGREEMENTS within the computer science community over the best way to protect software surfaced last week at a discussion meeting organized by the computer science and technology board of the National Academy of Sciences. Software has traditionally been protected through copyright laws, but researchers are increasingly taking out patents on their programmes, and are divided over the issue of whether patent protection should be strengthened or weakened.

Among the problems created by the recourse to patent law is the delay in processing applications at the US Patent and Trademark Office (PTO), and the ambiguity of some patents issued, which has on occasion erupted into expensive law suits. The PTO is also causing irritation among academics and industrialists in the computer science community by issuing patents for software that many consider too unoriginal to merit protection. Robert Spinrad of the Xerox Corporation complained that the confusion was having a "stultifying and dulling effect" on the industry. Dan Brinklin, now president of Software Garden Inc., who was forced to sell his former company after a successful but expensive patent dispute, said that the software industry is "very scared" by the patent process.

The debate centred upon what would best serve the public interest. John Schoch of Asset Management Company, a venture capital group based in California, argued strongly that patent protection must be strengthened as this encourages innovation and therefore benefits the public. But Anita Jones of the department of computer science of the University of Virginia argued that patent protection should be weakened because the public benefit lies chiefly in the unrestricted dissemination of information.

There was also disagreement over the use of copyright to protect software. Although some complain about the copyright system, it has the advantage of being enforceable worldwide through international copyright agreements.

Howard Figueroa, vice-president of commercial and industry relations at IBM Corporation, was among those who spoke strongly in favour of the current system which relies heavily on the use of copyright. His response to heated discussion between those who favour strengthening patent protection and those who would like to see it weakened was "if it ain't broke don't break it".

The 20-25 per cent annual growth in the computer software industry in the past 10 years proves that the current system is working, and the problems could easily be put right he argued.

Christine McGourty

Late award reveals problems

Tokyo

AFTER waiting for three decades, the US electronics giant Texas Instruments (TI) has been awarded a Japanese patent for the technology that forms the basis of nearly all integrated circuits. The patent is expected to bring in hundreds of millions of dollars in royalties and will provide a powerful bargaining tool for TI in renegotiations of cross-licensing agreements with Japan's electronics companies. But although TI has hailed the agreement as a new sign of respect for intellectual property rights in Japan, the prolonged process of patent application only highlights the problems that foreign companies face in protecting their rights in Japan.

The newly patented invention goes back to 1958 , when Jack Kilby, a TI engineer, showed how to build transistors, capacitors and resistors together on a semiconducting substrate to make an integrated circuit. A US patent was applied for in 1959 and awarded a few years later. A Japanese patent application was filed on 6 February 1960. But the Japanese patent office objected to the broadness of the application, which was then split into several smaller claims.

But still objections were raised and the proceedings delayed, and only on 27 November 1986 was the central part of the original patent application accepted and published by the patent office.

Many of Japan's electronics companies immediately filed opposition proceedings but finally, on 30 October this year, the patent was granted.

The Nihon Keizai Shimbun, a financial newspaper, reported the patent award two weeks ago and predicted that it could bring TI royalties of as much as $¥ 80,000$ million ( $\$ 550$ million) a year.

But most of Japan's semiconductor manufacturers already have cross-licensing agreements with TI, and they are expected to trade other technology rights, rather than pay royalties, when their agreements with TI come up for renewal in the next year or two.

But smaller manufacturers, as well as newcomers to the semiconductor trade, which do not have leading-edge technology to barter with, are expected to have to pay out large amounts in royalties, according to analysts.

Masahiro Miki, a spokesman for TI Japan, says the patent award shows the importance that Japan is now attaching to intellectual property rights. And he points to TI's success in suing Japanese and Korean companies in 1987 for violations of the company's patent rights for dynamic random access memory (DRAM) technology as another good men. But he refused to discuss why the Japanese patent office took more than 29 years to process the Kilby patent.

Compared to US patents, Japanese patents tend to be much more narrowly defined, each covering minute aspects of an innovation.

The Japanese patent office is flooded with about half a million patent applications a year, which take on average 5-7 years to process. In the United States, by contrast, 200,000 applications come in every year, and most are dealt with in 18 months.

According to Mitsuru Miyata, editor of the newsletter Nikkei Biotechnology, the Japanese patent system is designed not for the protection of intellectual property rights but rather for the import and use of foreign technology. Japanese companies seldom fight each other over patent rights, he says: instead, competitors go out of their way to file narrow patent applications that differ from each other in only some minor respect, allowing them to compete commercially without violating each other's patents.

When a foreign company tries to protect a broad technological invention in Japan, it is forced to break down the patent into a series of narrow applications, each of which has to fight its way through the system. The delays provide a crucial advantage for Japanese companies. If TI had been awarded its patent 5 or 10 years ago, it would have been a far greater financial burden for Japan's electronics giants, because they then lacked the sophisticated technology then they use in cross-licensing agreements with the US company.

This is not the first time the Kilby patent has been at the centre of confrontation between the United States and Japan over technology. In the 1960s, the Ministry of International Trade and Industry (MITI) rejected initial efforts by TI to set up operations in Japan, according to David Lammers of the Tokyo office of the Electronic Engineering Times. But the US company suggested that any Japanese integrated circuit incorporating the Kilby patent would be barred entry to the US market and so MITI backed down, Lammers says.

Although TI says the award of its patent is a sign of change for the better in Japan, the irony is that under present Japanese law the patent would never have been granted. Under current rules, a patent application expires 20 years after the application is filed or 15 years after publication, whichever comes first, says Yasunori Ohtsuka, a patent lawyer in Tokyo. But the TI application in 1960 was submitted just two months before the current law came into effect, and under the old law, which still applies to the US company's case, there is no time limit.

David Swinbanks 